\title{
The Effect of Lifestyle Modification Intervention with Motivational Construct on Dietary Macronutrient Intake among Obese Adults
}

\author{
Shahadan $S Z^{a}$, Daud $A^{a}$, Md. Isa $M L^{b}$, Ibrahim $M^{c}$, Deraman $S^{d}$ \\ ${ }^{a}$ Department of Medical Surgical Nursing, Kulliyyah of Nursing, IIUM, Kuantan. \\ ${ }^{\mathrm{b}}$ Department of Basic Medical Sciences for Nursing, Kulliyyah of Nursing, IIUM, Kuantan. \\ ${ }^{\mathrm{C}}$ Department of Nutrition, Kulliyyah of Allied Health Sciences, IIUM, Kuantan. \\ ${ }^{d}$ Department of Family Medicine, Kulliyyah of Medicine, IIUM, Kuantan.
}

\section{ABSTRACT}

Introduction: An unhealthy dietary practice as a result of environmental and societal changes is increasingly exposed to adults. These unhealthy practices lead to an increased cardiometabolic risk, and obese adults are at a higher risk as compared to normal-weight adults. The best strategy to promote healthy lifestyle practices among Malaysian obese adult is still fragmented. Materials and Methods: A single-centre randomised controlled trial was carried out to determine the effect of the lifestyle modification intervention (LMI) with the motivational construct, in comparison to the current standard LMI on the dietary macronutrient intake among obese adults. The dietary macronutrient intake and changes in body weight were assessed at baseline and after six months. Seventy-nine participants completed the study. Results: Our finding showed that six months of LMI with motivational construct resulted in a higher reduction of total fat and cholesterol from the dietary intake as compared to the control. In addition, the participants in the intervention group had a significant body weight loss after six months $(-1.97 \mathrm{~kg}, 95 \% \mathrm{Cl}:-0.324,1.360, t(39)=$ 3.397, $p=0.002$ ). Conclusion: This study demonstrates that the intervention had a meaningful impact on improving the dietary macronutrient intake, which is beneficial to support body weight loss in obese adults. Future trials with additional nutritional biomarkers are needed to extend these findings.

KEYWORDS: dietary intake, obesity, cardiometabolic risk, lifestyle modification intervention

\section{INTRODUCTION}

An unhealthy dietary practice as a result of environmental and societal changes is increasingly exposed to adults. Unhealthy dietary practice is a public health issue because it is the fundamental cause of the non-communicable diseases (NCDs), including obesity and cardiometabolic diseases, such as type 2 diabetes mellitus (T2DM) and cardiovascular disease (CVD). ${ }^{1}$ In Malaysia, previous observations showed that unhealthy dietary practices, such as skipping breakfast and eating fast food have contributed to obesity epidemics. ${ }^{2,3}$

Corresponding Author:

Dr Siti Zuhaidah Shahadan,

Kulliyyah of Nursing,

International Islamic University Malaysia (IIUM),

Kuantan, Pahang

Tel No : +60139360989,

Email : sitizuhaidah@iium.edu.my
Obesity is an abnormal or excessive fat accumulation that may impair health. ${ }^{1}$ There are several ways to define obesity, namely using the calculation of body mass index (BMI), waist circumference measurement, waist to hip ratio, skinfold thickness and high-tech imaging options, such as computed tomography (CT) and magnetic resonance imaging (MRI). Above all, BMI is the most inexpensive and most accessible, yet a reliable method to define obesity in adults. ${ }^{1,4}$ Globally, the United States of America (USA) Centre for Disease Control and Prevention (CDC), as well as the WHO, refers obesity as an adult with a BMI of $30.0 \mathrm{~kg} / \mathrm{m}^{2}$ and higher. ${ }^{5,6} \mathrm{In}$ contrast, the current Clinical Practice Guideline (CPG) of obesity refers adult obesity as an obese adult with BMl of $27.5 \mathrm{~kg} / \mathrm{m}^{2}$ and higher. ${ }^{4}$ A lower cut off points of BMI to define obesity in Malaysian adults might reflect that these populations are at a higher risk of developing obesity-related diseases, such as T2DM and CVD, including hypertension and coronary heart disease than the global population. ${ }^{4,7}$ 
The global prevalence of obesity in adults has been alarmingly high. ${ }^{7}$ According to the World Health Organization (WHO), the prevalence of obesity had a marked increase over the past four decades, and in 2014 , the prevalence of obesity ranged from $11 \%$ to $15 \%$ in men and women, respectively. ${ }^{8}$ Similarly, in Malaysia, the prevalence of obesity has been increasing by years. The Malaysian National Health and Morbidity Survey (NHMS) reports showed that the prevalence of obesity in adults has increased from $27.2 \%$ in 2011 to $30.6 \%$ in $2015 .{ }^{9}$ The NHMS 2015 also reported that the prevalence of obesity in Malaysian adults is higher than the global prevalence of obesity. ${ }^{9}$

An adult with obesity is at risk of multiple adverse effects regarding their health outcomes and the quality of health. Obesity affects health outcomes by causing insulin resistance, which later develops into T2DM and CVD. ${ }^{10,11}$ The insulin resistance also leads to various unfavourable pathways, which will result in the increased cardiometabolic risk (CMR) and poor health outcomes, including myocardial ischemia (MI), stroke, and even premature death. ${ }^{12-}$ ${ }^{14}$ Furthermore, obesity brings a significant negative impact on the quality of life of the individuals involved. Obesity causes limited mobility due to heaviness, reduced postural control, and stability. ${ }^{15}$ Later, a condition called accelerating sarcopenia may develop, where the progressive loss of skeletal muscle mass and strength occurs and causes the physical and functional disability. ${ }^{16}$

In the long term, physical and functional impairment can lead to unemployment and financial limitation. ${ }^{17,18}$ Other than affecting the physical and mobility, obesity also causes negative body image, low self-esteem and depression. ${ }^{4,19,20}$ Eventually, these psychological disturbances may interfere with the personal, social, and occupational activities of those involved, which will result in a reduced quality of life. ${ }^{21}$

Nonetheless, Gates et al. suggested that a modest weight loss may result in improved productivity among the obese adults and gives economic benefits to the employers. ${ }^{22}$ Henceforward, this study highlights the need for effective intervention that is targeted at improving the dietary macronutrient intake among the obese adults to improve the health outcomes and the quality of health, that substantially to reduce the economic impacts of obesity, particularly in Malaysia.
Across the world, there are three phases involved in the management of obesity, namely the LMI, pharmacological, and surgical intervention. The pharmacological and surgical intervention is used as an adjunct to the LMI. ${ }^{4}$ Six months of LMI is the initial component of treatment for the obese adults. The objective of the LMI is to achieve body weight loss by decreasing the calories consumption and increasing the energy use. Nevertheless, the approach of the standard LMI, which includes the screening and treatment session, is bounded to the hospital and primary care clinic setting. It is undeniable that those services have helped, but not everyone has access to the services. The accessibility of the health care services has been highlighted as one of the challenges in implementing the Tenth Malaysian Plan. ${ }^{23}$ Hence, this study believes that there is a gap in the practice of LMI for an adult with obesity in Malaysia. Therefore, this article aims to compare the effect of the standard LMI and the LMI with motivational construct on the dietary macronutrient intake after six months. In addition, the difference in the body weight changes among the participants after six months will be compared to support the findings on the dietary intake.

\section{Materials and Method}

\section{Study Design}

This study is a single centre randomised controlled trial with two parallel groups.

\section{Sample size calculation}

The sample size calculation was determined based on the prevalence of obesity class I and II (body mass index ranged between 27.5 and $39.9 \mathrm{~kg} / \mathrm{m}^{2}$ ) adults (aged 18 years and above) in Pahang, as reported in the National Health and Morbidity Survey (NHMS) $2015^{9}$. From the calculation using a single proportion formula from an online Open Epi sample size calculator (Version 3), the estimated sample size as calculated was 112 participants. In addition, considering a dropout rate of $10 \%$, the sample size required was 123 participants to obtain a representative of obese class I and II adults in Pahang.

\section{Participants and procedure}

The participants of this study were recruited through an advertisement in the social media networks. All 
potential participants were invited to a screening and were selected based on the inclusion and exclusion criteria at the university primary care clinic. The inclusion criteria include age range between 19 and 60 years old confirmed by the identification card, obese with the body mass index (BMI) ranged between $27.5 \mathrm{~kg} / \mathrm{m}^{2}$ and $39.9 \mathrm{~kg} / \mathrm{m}^{2}$ confirmed by taking the measurement of the height and body weight and are able to speak and write in the Malay or English language. The BMI range was pre-specified to ensure the homogeneity of the study population, and the ability to speak and write in Malay or English language was necessary because the intervention was delivered in either Malay or English language only. On the other hand, the exclusion criteria include self-reported of any comorbidity, such as type 2 diabetes mellitus (T2DM) or thyroid disorders. Furthermore, pregnant and lactating women were excluded because they have different recommended nutrient intakes. Also, their medical history was assessed to ensure that the participants were not taking any medication and are not actively involved in any diet and fitness program.

After the screening, the participants were briefed on this study, including the purpose of the study, the risk, and benefits of the study, the responsibility as a participant in this study, the procedures involved, the compensation available to the participant, the facts that the participation is voluntary, which means that the participant may refuse or withdraw from the trial at any time without any penalty, the confidentiality of the records, the expected duration of the study, and the person to contact for any trial-related matters throughout this study period. When the participant is fully informed and understand all the trialrelated matters, the participants were asked to sign and write down the date personally on the written informed consent form. The researcher and the witness then signed and dated the informed consent form. A copy of the informed consent form was given to the participants for reference. After obtaining the written informed consent, the participants were randomised to two groups; the intervention (LMI with motivational construct) and control (standard LMI) group. To obtain equal sample sizes in each group, this study used the block randomisation technique. Upon randomisation, the intervention and control group received the allocated treatments.
The standard LMI is one session of lifestyle advice, mainly to describe the energy value of different Malaysian foods, to describe the food composition, such as fats, carbohydrates, fibres, and protein, to teach how to evaluate the nutrition labels to determine the caloric content and food composition, to develop the preferences for low-calorie, highprotein and low-fat foods and their food exchanges, and to educate on food preparation and describe the importance of adequate water intake. The standard treatment was performed by the same person to avoid any possible confounding factors. For the intervention, an additional motivational construct was added to the standard LMI and is referred to as the LMI with the motivational construct. The intervention was designed based on the informationmotivation-behaviour (IMB) model proposed by J. Fisher and W. Fisher in 1992. ${ }^{24}$ The intervention involved the one session of standard LMI with additional monthly home visit sessions with an average of 50 to 60 minutes per session. During the follow-up, the researcher motivates the participants for dietary modification by tailored lifestyle advice. The monthly follow-up was conducted at places preferred by the participants.

The CONSORT participation flowchart illustrated the flow of the study from the enrolment phase up to the analysis (see Figure 1). Throughout the six months of the intervention period, ten participants from the control group and nine participants in the intervention group were lost to follow-up. In the end, the final analysis reported a total of 79 participants, with 39 participants in the control group and 40 participants in the intervention group.

\section{Outcomes measurements}

The outcome of this study is to look at the dietary macronutrient intake of the participants at pre and post-intervention, which is assessed using the 24 hours dietary recall. During the assessment of the 24 -hour dietary recall, the participants were asked to recall all food consumed during the previous day and to estimate the quantities in common measures or servings. The raw data from the 24-hours dietary recall were then entered into the Nutritionist Pro $^{\text {TM }}$ software that converts the raw data into the seven outcome measures, namely total energy (kcal), protein (g), carbohydrate (g), total fat (g), cholesterol $(\mathrm{mg})$, total dietary fibre $(\mathrm{g})$, and total sugar (g). 


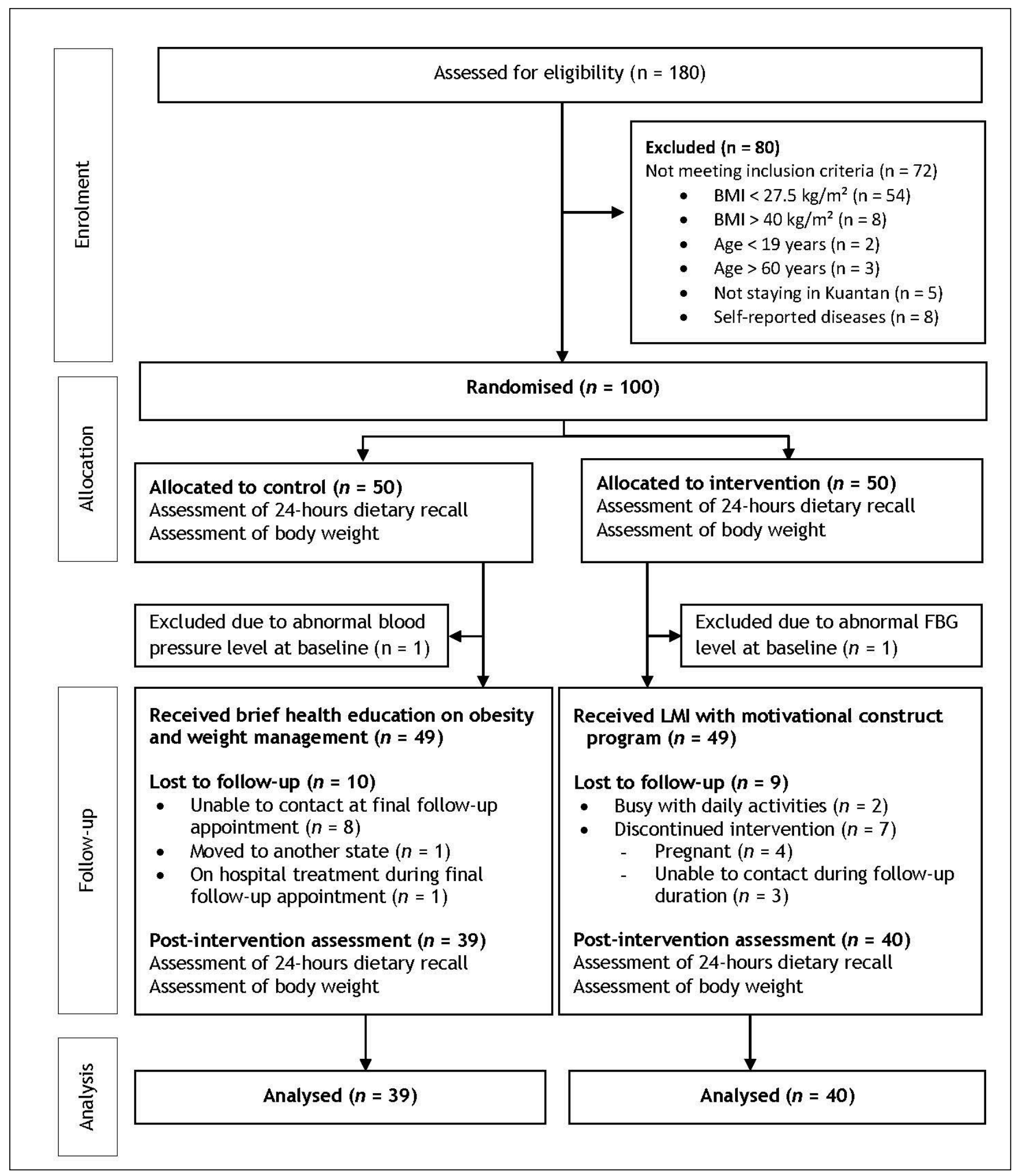

Figure I: The CONSORT Participants Flowchart of Intervention and Control Group

In addition, the body weight of the participants was assessed at pre- and post-intervention, using zero calibrated Seca ${ }^{\mathrm{TM}}$ digital column scale with BMI function (model 769).

The participants were weighed while wearing light clothing and no shoes. Height and weight were measured to the nearest $0.5 \mathrm{~cm}$ and $0.5 \mathrm{~kg}$, respectively.
The descriptive statistics (the mean \pm standard deviation and the frequency and percentage) was used to describe the baseline data. Then, the inferential statistics, which are independent t-test to determine the difference between the groups and paired $\mathrm{t}$-tests to determine the difference between the pre- and post-intervention groups were utilised. An intention-to-treat analysis is performed to report the findings of this study. 


\section{RESULTS}

\section{Sample characteristics}

A total of 79 obese adults were randomised into the intervention and control group. On average, the mean \pm SD age of the participants is $33 \pm 8.97$ years old. All participants in this study are Malay. The majority of the participants are married $(57.0 \%)$, employed (54.4\%), a degree holder (35.4\%), and never smoke $(88.6 \%)$. There is no difference between the intervention and control group regarding the demographic background ( $\mathrm{p}$-value > 0.05) (refer to Table I).

Attendance of Study Participants in the Intervention Group

Throughout the six months of the intervention period, efforts are made to maintain the optimal adherence to the LMI with motivational construct program. The participants in the intervention group were frequently reminded of the follow-up sessions. Six sessions were allocated for participants in the LMI with the motivational construct group. Using the formula of attendance rate, the average \pm SD percentage of attendance of the participants in the intervention group $(\mathrm{n}=40)$ to the LMI with motivational construct sessions is $50.5 \pm 17.7 \%$. The attendance rate does not vary among between male $(n=13,50 \%)$ and female $(n=27,52.5 \%)$ participants but decreases with increasing age and monthly income. In addition, the attendance rate for the follow-up session was higher among single adults (non-married [54.8\%] and widower [66.7\%]) than married adults (37.2\%).

Adverse Effect Reporting

Attendance rate $(96)=\left(\frac{\text { individual number of attendance }}{\text { Six sessions }}\right) \times 100$

No serious adverse event attributed to the intervention was reported. Two adverse events, defined as abnormal blood pressure $(n=1)$ and abnormal fasting blood glucose level $(n=1)$ during the study period (after the process of randomisation), were reported and excluded from the study to prevent any potential harm to the participants.

The effect of $L M I$ on dietary macronutrient intake in obese adults

Table II reported that the mean $\pm \mathrm{SE}$ (standard error) of the dietary macronutrient intake of the study participants that is defined by the allocated groups. The findings show that the mean total energy intake of the study participants after six months was reduced in both groups with a mean reduction of $179 \mathrm{kcal}$ per day for the control group and $71 \mathrm{kcal}$ per day for the intervention group. With regards to the protein intake after six months, participants in both the intervention and control group consumed lower intake of protein (20 gram per day in control and $-13 \mathrm{~g}$ per day in the intervention group). Pertaining to the carbohydrate intake, the participants in the intervention and control group consumed an average of $219 \mathrm{~g}$ of carbohydrate in a day, after six months. The control group had reduced the carbohydrate intake ( -9 gram per day) after six months. On the other hand, the intervention group had more carbohydrate intake after six months (+15 gram per day).

Next, the findings of this study showed that the total dietary fibre intake was also reduced in both groups, with a higher reduction in the control group $(-1.56$ gram per day) compared to the intervention group (0.81 gram per day). Concerning the dietary fat intake, both groups showed a reduction in the total dietary fat intake, with more reduction in the intervention group (-8.5 gram per day) compared to control group (-7.4 gram per day). For the cholesterol intake, the intervention showed to have a higher reduction in the dietary cholesterol intake ( $-73 \mathrm{mg}$ per day) compared to the control group ( $-23 \mathrm{mg}$ per day) after six months. Additionally, the findings showed that both groups had consumed higher total sugar intake after six months (+1.1 gram per day for control and 5.6 gram per day for intervention group). Regardless, the statistical analysis reported that there was no significant difference between the pre- and post-test values in all variables of dietary intake. The independent sample $t$ test also revealed that there is no significant difference between the intervention and control group on the dietary intake after six months (refer to Table II).

\section{The effect of $L M I$ on body weight in obese adults}

In addition, the comparison between the intervention and control group on the changes in body weight after six months was measured. Figure II presents the percentage of participants in the study who had lost, maintained, or gained body weight after six months since the baseline measurements. The findings show that a total of $70 \%$ of participants in the intervention group achieved body weight loss, while $46.2 \%$ of the participants in the control group achieved weight loss. 
Table I: The characteristics of the study participants ( $\mathrm{n}$ =79)

\begin{tabular}{|c|c|c|c|}
\hline Variables & $\begin{array}{l}\text { Total } \\
(\mathrm{N}=79)\end{array}$ & $\begin{array}{l}\text { Control } \\
(n=39)\end{array}$ & $\begin{array}{l}\text { Intervention } \\
(\mathrm{n}=40)\end{array}$ \\
\hline $\begin{array}{l}\text { Age (years } \pm \\
\text { SD)* }\end{array}$ & $\begin{array}{l}32.72 \pm \\
8.97\end{array}$ & $\begin{array}{l}33.21 \pm \\
10.35\end{array}$ & $32.08 \pm 7.83$ \\
\hline \multicolumn{4}{|l|}{ Gender } \\
\hline Men & $24(30.4)$ & $11(28.2)$ & $13(32.5)$ \\
\hline Women & $55(69.6)$ & $28(71.8)$ & 27 (67.5) \\
\hline \multicolumn{4}{|l|}{$\begin{array}{l}\text { Employment } \\
\text { status }\end{array}$} \\
\hline Homemaker & $10(12.7)$ & $6(15.5)$ & 4 (10.0) \\
\hline Employed & $43(54.4)$ & $20(51.3)$ & $23(57.5)$ \\
\hline Unemployed & $1(1.3)$ & $1(2.6)$ & $0(0)$ \\
\hline $\begin{array}{l}\text { Student } \\
\text { Marital status }\end{array}$ & $25(31.6)$ & $12(30.8)$ & $13(32.5)$ \\
\hline Single & & & \\
\hline Married & $31(39.2)$ & $17(43.6)$ & $14(35.0)$ \\
\hline Divorced/ & $45(57.0)$ & $21(53.8)$ & $24(60.0)$ \\
\hline Widowed & $3(3.8)$ & $1(2.6)$ & $2(5.0)$ \\
\hline \multicolumn{4}{|l|}{$\begin{array}{l}\text { Educational } \\
\text { status }\end{array}$} \\
\hline Certificates & $2(2.5)$ & $2(5.1)$ & $0(0)$ \\
\hline $\begin{array}{l}\text { Sijil Pelajaran } \\
\text { Malaysia }\end{array}$ & $17(21.5)$ & $10(25.6)$ & 7 (17.5) \\
\hline Matriculation & $14(17.7)$ & 9 (23.1) & $5(12.5)$ \\
\hline Diploma & 9 (11.4) & $2(5.1)$ & 7 (17.5) \\
\hline Degree & $28(35.4)$ & $14(35.9)$ & $14(35.0)$ \\
\hline Master & 7 (8.9) & $0(0)$ & 7 (17.5) \\
\hline $\begin{array}{l}\text { Doctor of } \\
\text { philosophy }\end{array}$ & $2(2.5)$ & $2(5.1)$ & $0(0)$ \\
\hline $\begin{array}{l}\text { Monthly } \\
\text { income } \\
\text { (RM } \pm \text { SD)* } \\
\text { Smoking status }\end{array}$ & $\begin{array}{l}1502.94 \pm \\
2052.57\end{array}$ & $\begin{array}{l}1502.94 \pm \\
2052.57\end{array}$ & $\begin{array}{l}1841.63 \pm \\
1999.78\end{array}$ \\
\hline Smoker & $4(5.1)$ & $2(5.1)$ & $2(5.0)$ \\
\hline $\begin{array}{l}\text { Former } \\
\text { smoker }\end{array}$ & $5(6.3)$ & $3(7.7)$ & $2(5.0)$ \\
\hline Never smoke & $70(88.6)$ & $34(87.2)$ & $36(90.0)$ \\
\hline
\end{tabular}

All data presented as frequency (\%)

* Data is presented in mean \pm SD

Likewise, $5.1 \%$ of participants in the control group maintained their body weight after six months, whereas none in the intervention group had maintained the same body weight since baseline measurement. Importantly, the findings showed that there was a lower percentage of participants with body weight regained in the intervention group (30 $\%)$ as compared to the control group (48.7\%). Based on the paired t-test, the intervention group had a significant reduction in the body weight after six months $(-1.97 \mathrm{~kg}, 95 \% \mathrm{Cl}:-0.324,1.360, t(39)=$ 3.397, $p=0.002)$. An independent $\mathrm{t}$-test indicates that there was a significant difference in the body weight changes after six months between the intervention and control group $(\mathrm{p}=0.46,95 \% \mathrm{Cl}$ : $0.024,2.875, t[77]=2.024)$.

\section{DISCUSSION}

The purpose of this study was to determine the effect of LMI with motivational construct program, in omparison to the standard LMI on the dietary macronutrient intake and the changes in body weight among obese adults after six months. The current study indicates that the obese adults in the intervention group had more reduction in the total fat from the dietary intake (-8.52 gram per day, $95 \%$ $\mathrm{Cl}:-6.57,23.61)$ as compared to the control group (7.37 gram per day, $95 \% \mathrm{Cl}:-5.03,19.78)$ after six months. Dietary fat is a source of energy other than protein and carbohydrates. Each gram of dietary fat provides nine kilocalories, whereas protein and carbohydrate only provide four kilocalories per gram. ${ }^{25}$ Dietary fat is also referred to as lipids, which are composed of a carbon skeleton with hydrogen and oxygen substitutions. ${ }^{26}$ An adequate amount of dietary fat is essential to insulate the body against extreme temperature, to provide padding for internal organs, and also to maintain the absorption of fatsoluble vitamins, such as vitamins $A, D, E$, and $K$, and carotenoids from food. ${ }^{27}$ Nonetheless, an excessive intake of dietary fat is detrimental to the human body. An excessive amount of dietary fat intake is associated with obesity and other CVD risk factors, including hypercholesterolemia, hypertriglyceridemia, and metabolic syndrome. ${ }^{28}$ On top of that, the obese adults in the intervention group also demonstrated a meaningful reduction in cholesterol intake per day (-73.04 mg per day, 95\% $\mathrm{Cl}:-23.72,169.79)$ compared to the control group ($23.02 \mathrm{mg}$ per day, $95 \% \mathrm{Cl}:-63.13,109.18)$, after six months. A reduction of cholesterol consumption was associated with lower risk of CVD. ${ }^{29}$ Thus, a higher reduction of the total fat and cholesterol from the dietary intake among obese adults in the intervention group may be helpful to reduce the risk of mortality due to CVD.

In addition, the results of this study reveal that the obese adults in both groups consumed a higher amount of total sugar from the dietary intake after six months. The finding was consistent with a study conducted by Ammara et al. who stated that Malaysian adults had a high sugar intake. ${ }^{30}$ The high sugar intake has been found to be correlated with increased cardiometabolic risk. ${ }^{31}$ Nonetheless, Mandel and Brannon highlighted that despite the government's effort in preventing obesity, it is still more convenient to obtain food that contains a high amount of sugar and added sugar than the healthy foods. ${ }^{32}$ A similar circumstance is happening in Malaysia. The highly commercialised food with high sugar contents in Malaysia might influence the high sugar intake among the obese adults. ${ }^{33}$ Therefore, 
Table II: Changes in the dietary macronutrient intake of LMI with motivational construct and control group ( $\mathrm{n}=79$ )

\begin{tabular}{|c|c|c|c|c|c|c|c|}
\hline $\begin{array}{l}\text { Dietary } \\
\text { intake }\end{array}$ & Pre-test & Post-test & $m_{d} \pm S E_{d}$ & $95 \% \mathrm{Cl}$ & $t(d f)$ & $p$-value ${ }^{a}$ & $p$-value \\
\hline \multicolumn{8}{|l|}{$\begin{array}{l}\text { Total energy } \\
\text { (kcal/day) }\end{array}$} \\
\hline \multirow{2}{*}{$\begin{array}{l}\text { Control } \\
(n=39) \\
\text { Intervention } \\
(n=40)\end{array}$} & \multirow{2}{*}{$\begin{array}{c}1832.29 \pm \\
121.46 \\
1671.14 \pm \\
93.31\end{array}$} & \multirow{2}{*}{$\begin{array}{c}1653.42 \pm \\
113.55 \\
1600.24 \pm \\
117.43\end{array}$} & \multirow{2}{*}{$\begin{array}{l}-178.88 \\
\pm 156.58 \\
-70.90 \pm \\
157.95\end{array}$} & \multirow{2}{*}{$\begin{array}{c}-138.10 \\
495.86 \\
-248.58 \\
390.38\end{array}$} & $1.142(38)$ & 0.260 & \multirow{2}{*}{0.746} \\
\hline & & & & & $0.449(39)$ & 0.656 & \\
\hline \multicolumn{8}{|l|}{$\begin{array}{l}\text { Protein (g/ } \\
\text { day) }\end{array}$} \\
\hline \multirow{3}{*}{$\begin{array}{l}\text { Control } \\
(n=39) \\
\text { Intervention } \\
(n=40) \\
\text { Carbohydrate } \\
\text { (mg/day) }\end{array}$} & \multirow{2}{*}{$\begin{array}{c}83.21 \pm \\
10.83 \\
75.31 \pm \\
4.41\end{array}$} & $63.64 \pm 5.12$ & \multirow{2}{*}{$\begin{array}{c}-19.57 \pm \\
12.17 \pm \\
-12.66 \pm \\
6.46\end{array}$} & \multirow{2}{*}{$\begin{array}{l}-5.08 \\
44.21 \\
-0.40 \\
25.73\end{array}$} & $1.607(38)$ & \multirow{2}{*}{$\begin{array}{l}0.116 \\
0.057\end{array}$} & \multirow{2}{*}{0.997} \\
\hline & & $62.65 \pm 4.46$ & & & $1.960(39)$ & & \\
\hline & & & & & & & \\
\hline \multirow{2}{*}{$\begin{array}{l}\text { Control } \\
(n=39) \\
\text { Intervention } \\
(n=40)\end{array}$} & \multirow{2}{*}{$\begin{array}{l}228.11 \pm \\
16.76 \\
204.00 \pm \\
13.16\end{array}$} & \multirow{2}{*}{$\begin{array}{c}218.65 \pm \\
15.48 \\
218.75 \pm \\
16.80\end{array}$} & \multirow{2}{*}{$\begin{array}{c}-9.46 \pm \\
21.86 \\
14.75 \pm \\
20.95\end{array}$} & \multirow{2}{*}{$\begin{array}{c}-34.79 \\
53.71 \\
-57.12 \\
27.62\end{array}$} & $0.433(38)$ & 0.668 & \multirow{2}{*}{0.884} \\
\hline & & & & & $-0.704(39)$ & 0.486 & \\
\hline \multicolumn{8}{|l|}{$\begin{array}{l}\text { Total fat (kcal/ } \\
\text { day) }\end{array}$} \\
\hline \multirow{2}{*}{$\begin{array}{l}\text { Control } \\
(n=39) \\
\text { Intervention } \\
(n=40)\end{array}$} & \multirow{3}{*}{$\begin{array}{c}66.71 \pm \\
4.36 \\
62.53 \pm \\
4.19\end{array}$} & \multirow{3}{*}{$\begin{array}{c}59.33 \pm \\
5.05 \\
54.01 \pm \\
5.10\end{array}$} & \multirow{3}{*}{$\begin{array}{c}-7.37 \pm \\
6.13 \\
-8.52 \pm \\
7.46\end{array}$} & \multirow{3}{*}{$\begin{array}{l}-5.03 \\
19.78 \\
-6.57 \\
23.61\end{array}$} & $1.203(38)$ & 0.236 & \multirow{2}{*}{0.101} \\
\hline & & & & & $1.142(39)$ & 0.260 & \\
\hline \multicolumn{4}{|l|}{$\begin{array}{l}\text { Cholesterol } \\
\text { (mg/day) }\end{array}$} & & & & \\
\hline \multirow{2}{*}{$\begin{array}{l}\text { Control } \\
(n=39) \\
\text { Intervention } \\
(n=40)\end{array}$} & \multirow{2}{*}{$\begin{array}{c}237.94 \pm \\
30.81 \pm \\
306.74 \pm \\
31.61\end{array}$} & \multirow{2}{*}{$\begin{array}{c}214.92 \pm \\
26.02 \pm \\
233.70 \pm \\
32.78\end{array}$} & \multirow{2}{*}{$\begin{array}{c}-23.02 \pm \\
42.56 \\
-73.04 \pm \\
47.83\end{array}$} & \multirow{2}{*}{$\begin{array}{l}-63.13 \\
109.18 \\
-23.72 \\
169.79\end{array}$} & $0.541(38)$ & 0.592 & 0.583 \\
\hline & & & & & $1.527(39)$ & 0.135 & 0.303 \\
\hline Total dietary fi & (g/day) & & & & & & \\
\hline $\begin{array}{l}\text { Control } \\
(n=39)\end{array}$ & $\begin{array}{c}7.39 \pm \\
1.11\end{array}$ & $\begin{array}{l}5.83 \pm \\
0.85\end{array}$ & $\begin{array}{l}-1.56 \pm \\
1.39\end{array}$ & $\begin{array}{l}-1.25 \\
4.36\end{array}$ & $1.124(38)$ & 0.268 & \\
\hline $\begin{array}{l}\text { Intervention } \\
(n=40)\end{array}$ & $\begin{array}{l}5.75 \pm \\
0.96\end{array}$ & $\begin{array}{l}4.94 \pm \\
0.62\end{array}$ & $-0.81 \pm$ & $\begin{array}{l}-1.51 \\
3.13\end{array}$ & $0.704(39)$ & 0.486 & 0.461 \\
\hline $\begin{array}{l}\text { Total sugar } \\
\text { (g/day) }\end{array}$ & & & & & & & \\
\hline $\begin{array}{l}\text { Control } \\
(n=39)\end{array}$ & $\begin{array}{c}36.95 \pm \\
4.11\end{array}$ & $\begin{array}{c}38.02 \pm \\
6.03\end{array}$ & $\begin{array}{l}1.07 \pm \\
7.01\end{array}$ & $\begin{array}{l}-15.26 \\
13.13\end{array}$ & $-0.152(38)$ & 0.880 & \\
\hline $\begin{array}{l}\text { Intervention } \\
(n=40)\end{array}$ & $\begin{array}{c}37.56 \pm \\
4.71 \\
\end{array}$ & $\begin{array}{c}43.19 \pm \\
7.17\end{array}$ & $\begin{array}{l}5.63 \pm \\
8.77 \\
\end{array}$ & $\begin{array}{r}-23.38 \\
12.11 \\
\end{array}$ & $-0.642(39)$ & 0.525 & 656 \\
\hline
\end{tabular}

more efforts to reduce the high sugar from the dietary intake by means of an absolute limitation on the advertisement and the commercialisation of unhealthy food with high sugar content by Malaysian regulatory authority or more health campaign is warranted.
This way, the Malaysian population would be able to avoid the temptation of unhealthy food, thus, promotes a better dietary practice among Malaysian, especially the obese adults.

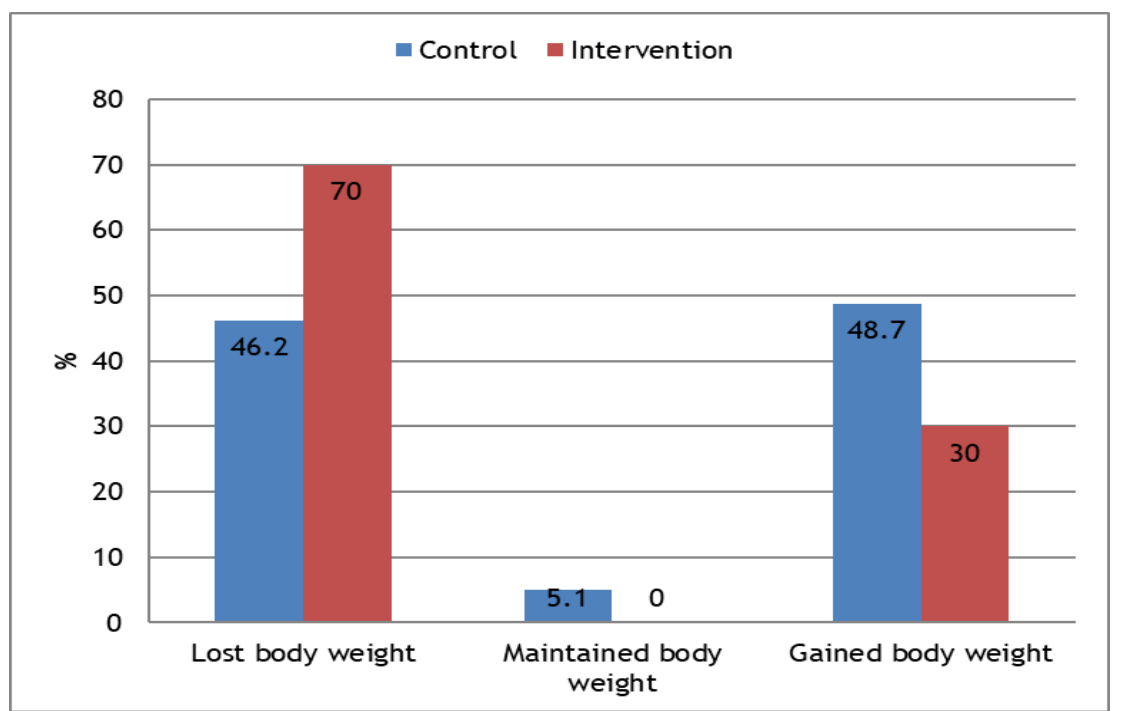

Figure II: The percentage of participants that have lost maintained, or gained body weight after six months $(\mathrm{n}=79)$ 
Moreover, the findings of this study also showed that the obese adults in both groups had a higher reduction in the total energy consumption. A reduction of the total energy consumption can produce a clinically significant impact on the body. ${ }^{4}$ According to Most et al., the energy or caloric reduction is an effective strategy to reduce the risk of CVD by decreasing adiposity ${ }^{34}$ The finding is supported by the achievement of the obese adults in this study to lose weight after six months. In particular, $70 \%$ of the obese adults in the intervention group and $46.2 \%$ in the control group were able to achieve weight loss. The caloric reduction has been recommended as a treatment strategy for obese adults since decades ago because it leads to a negative energy balance, which is referred to a more energy expenditure than the caloric intake that is essential to achieve weight loss. ${ }^{4,35,36}$ In addition, caloric restriction is also beneficial to reduce food craving among obese adults. ${ }^{37}$ Therefore, future studies should consider determining the effect of LMI with motivational construct on promoting a long-term caloric reduction in the effort to promote more weight loss and reduce CVD mortality rates among obese adults. Besides, the assessment of the 24-hours physical activity level may be useful to evaluate the energy balance among the obese adults.

To conclude, the findings of this study suggest that the motivational construct added to the standard LMI might have more potential to promote significant changes in the body weight after six months and in encouraging a lower consumption of total fat and cholesterol from the dietary intake among obese adults. Therefore, the strategies applied to increase the motivation of the obese adults to practice a healthy diet include tailored lifestyle advice, home visit approach, and monthly follow up, should be continued and may become part of the solution to reduce the epidemics of obesity in Malaysia. Even so, future studies with larger sample size, a longer duration of follow up and more robust outcome measure are highly suggested.

\section{Limitation of study}

The strength of this study includes a relatively homogenous sample population, with respect to the ethnicity and the obesity level. Having a homogenous group will reduce the potential bias and confounding factors due to the population stratification. ${ }^{38}$ Although this study has a homogenous sample population that will reduce the potential bias and confounding factors, one of the limitations is the small sample size. A relatively small sample size of this study might abandon several trends in terms of the dietary habit observed across the Malaysian population. Also, a relatively small sample size of this study might also influence the non-significant findings of this study. Other than that, the low attendance of the participants in the intervention group might have affected the finding of this study. In addition, the assessment of only one day (weekdays) of dietary macronutrient intake might not represent the actual dietary habit of the study participants.

\section{ACKNOWLEDGEMENTS}

This work has been supported by IIUM under the Research Initiative Grant Scheme (RIGS) with project ID RIGS 16-283-0447. The authors wish to express their gratitude to the staffs of Primary Care Clinic of a public university in Kuantan, Malaysia, who helped carry out the research.

\section{References}

1. World Health Organization. Factsheet: Obesity and Overweight [Internet]. 2014 [cited 2014 Nov 6]. p. 1-5. Available from: http://www.who.int/ mediacentre/factsheets/fs311/en/\#

2. Bachok N. Gaya Hidup Sihat Mengatasi Obesiti. First edit. Kuala Lumpur, Malaysia: Dewan Bahasa dan Pustaka; 2014. 124 p.

3. Abdull Hakim NH, Muniandy ND, Ajau Danish. Nutritional Status and Eating Practices among University Students in Selected Universities in Selangor, Malaysia. Asian Journal of Clinical Nutrition. 2012;4:77-87.

4. Ministry of Health Malaysia. Clinical Practice Guidelines on Management of Obesity. Kuala Lumpur: Ministry of Health Malaysia; 2004.

5. Centers for Disease Control and Prevention. Defining Adult Overweight and Obesity [Internet]. 2016 [cited 2017 May 26]. Available from: https://www.cdc.gov/obesity/adult/ defining.html

6. WHO Expert Consultation. Appropriate BodyMass Index for Asian Populations and Its Implications for Policy and Intervention Strategies. Lancet. 2004;363:157-63.

7. Blackstone RP. Epidemiology, Measurement, and Cost of Obesity. In: Obesity: The Medical 
Practitioner's Essential Guide. Switzerland: Springer International Publishing; 2016. p. 122.

8. World Health Organization. Global Health Observatory (GHO) data: Overweight and obesity [Internet]. 2015 [cited 2017 May 26]. Available from: http://www.who.int/gho/ncd/ risk_factors/overweight_text/en/

9. Institute for Public Health [IPH]. National Health and Morbidity Survey 2015: Vol II: NonCommunicable Diseases, Risk Factors \& Other Health Problems. Malaysia; 2015.

10. Karki S, Ngo DT, Bigornia SJ, Farb MG, Gokce N. Insulin Resistance: A Key Therapeutic Target for Cardiovascular Risk Reduction in Obese Patients? Expert Review of Endocrinology \& Metabolism. 2014;9:93-5.

11. Aung K, Lorenzo C, Hinojosa MA, Haffner SM. Risk of Developing Diabetes and Cardiovascular Disease in Metabolically Unhealthy NormalWeight and Metabolically Healthy Obese Individuals. Journal of Clinical Endocrinology and Metabolism. 2014;99:462-8.

12. Chen C-M, Yeh MC. The prevalence and determinants of impaired fasting glucose in the population of Taiwan. BMC public health. 2013;13:1123.

13. Cefalu WT. Insulin Resistance and Cardiometabolic Risk. In: Cefalu WT, Cannon $\mathrm{CP}$, editors. Atlas of Cardiometabolic Risk. 1st ed. New York: Informa Healthcare; 2007. p. 27 -38 .

14. Ehrlich SD. Atherosclerosis [Internet]. University of Maryland Medical Center. 2013 [cited 2015 Mar 2]. Available from: http:// umm.edu/health/medical/altmed/condition/ atherosclerosis

15. Forhan M, Gill S V. Obesity, Functional Mobility and Quality of Life. Best Practice and Research: Clinical Endocrinology and Metabolism. 2013;27:129-37.

16. Anton SD, Karabetian C, Naugle K, Buford TW. Obesity and Diabetes as Accelerators of Functional Decline: Can Lifestyle Interventions Maintain Functional Status in High Risk Older Adults? Experimental Gerontology. 2013;48:888 $-97$.

17. Kang HT, Lee HR, Lee YJ, Linton J a., Shim JY. Relationship between Employment Status and Obesity in A Korean Elderly Population, Based On The 2007-2009 Korean National Health And Nutrition Examination Survey (KNHANES).
Archives of Gerontology and Geriatrics. 2013;57:54-9.

18. Cheah YK. Factors Influencing Consumer Purchase Decisions for Health-Promoting Goods and Services in Malaysia. Malays J Med Sci. 2014;21:36-44.

19. Moy FM, Bulgiba A. The Modified NCEP ATP III Criteria Maybe Better Than the IDF Criteria in Diagnosing Metabolic Syndrome Among Malays in Kuala Lumpur. BMC public health. 2010;10:678.

20. Lo Coco G, Gullo S, Salerno L, lacoponelli R. The Association Among Interpersonal Problems, Binge Behaviors, and Self-Esteem, in the Assessment of Obese Individuals. Comprehensive Psychiatry. 2011;52:164-70.

21. Lean MEJ. Management of Obesity and Overweight. Medicine. 2011;39:32-8.

22. Gates D, Singler M, Poeppelman A, Succop P. Prevalence of Obesity and Cardiovascular Risk Factors Among Manufacturing Company Employees in Kentucky. 2007;55:397-407.

23. Ministry of Health Malaysia. Country Health Plan 2011 - 2015. Putrajaya, Malaysia: Ministry of Health, Malaysia; 2011. 11-15 p.

24. Fisher J, Fisher W, Williams S., Malloy T. Empirical Tests of an Information-MotivationBehavioral Skills Model of AIDS-Preventive Behavior With Gay Men and Heterosexual University Students. Health psychology. 1994;13:238-50.

25. Tan SY. Effects of Different Dietary Fatty Acids on Human Energy Balance, Body Weight, Fat Mass, And Abdominal Fat. In: Nutrition in the Prevention and Treatment of Abdominal Obesity. Amsterdam: Elsevier Inc; 2014.

26. Bruce AG, Cunnane SC. Nutrition and Metabolism of Lipids. In: Gibney MJ, LanhamNew SA, Cassidy A, Vorster HH, editors. Introduction to Human Nutrition. 2nd ed. United Kingdom: Wiley-Blackwell; 2009. p. 86.

27. Pinheiro MM, Wilson T. Dietary Fat: The Good, the Bad, and the Ugly. In: Temple N, Wilson T, Bray G, editors. Nutrition Guide for Physicians and Related Healthcare Professionals. Humana Press, Cham; 2017. p. 241-7.

28. National Coordinating Committee on Food and Nutrition [NCCFN]. Recommended Nutrients Intake for Malaysia. Malaysia: Ministry of Health Malaysia; 2017.

29. Takruri HR, Alkurd RA. Intakes of Fats, Cholesterol, Fiber and Micronutrients as Risk 
Factors for Cardiovascular Disease in Jordan. Jordan Journal of Biological Science.

2014;7:119-26.

30. Ammara MS V, Khor GL, Chan P. Intake of Added Sugar in Malaysia: A review. Asia Pacific Journal of Clinical Nutrition. 2016;25:227-40.

31. Ahima RS. Metabolic syndrome - A

Comprehensive Textbook. 1st ed. Ahima RS, editor. Vol. 43, Springer Reference.

Switzerland: SpringerNature; 2016. 1-880 p.

32. Mandel N, Brannon D. Sugar, Perceived

Healthfulness, and Satiety: When Does a Sugary

Preload Lead People to Eat More? Appetite. 2017;114:338-49.

33. Bridget K, Karuthan C, Tilakavati K. Obesogenic Television Food Advertising to Children in Malaysia: Sociocultural Variations. Global Health Action. 2014;7:1-11.

34. Most J, Tosti V, Redman LM, Fontana L. Calorie Restriction in Humans: An Update. Ageing Research Reviews. 2017;39:36-45.

35. Ahmad NN, Butsch WS, Aidarous S. Clinical Management of Obesity in Women: Addressing a Lifecycle of Risk. Obstetrics and Gynecology Clinics of North America. 2016;43:201-30.

36. Gonzalez-Campoy JM, St Jeor ST, Castorino K, Ebrahim A, Hurley D, Jovanovic L, et al. Clinical Practice Guidelines for Healthy Eating for the Prevention and Treatment of Metabolic and Endocrine Diseases in Adults. Endocrine Practice. 2013;19:1-82.

37. Kahathuduwa CN, Binks M, Martin CK, Dawson JA. Extended Calorie Restriction Suppresses Overall and Specific Food Cravings: A Systematic Review and a Meta-Analysis. Obesity Reviews. 2017;18:1122-35.

38. Hu FB. Genetic Predictors of Obesity. In: Hu FB, editor. Obesity Epidemiology. New York: Oxford University Press; 2008. p. 437. 